\title{
EXPERIMENTAL INVESTIGATION OF BEHAVIOUR OF MASONRY INFILLED RC FRAMES UNDER OUT-OF-PLANE LOADING
}

\author{
Aleksa Milijaš ${ }^{\text {** }}$ Bogdan Šakić ${ }^{1}$, Marko Marinković ${ }^{2}$ Christoph Butenweg ${ }^{3}$, \\ Sven Klinkel ${ }^{1}$ \\ ${ }^{1}$ Chair of Structural Analysis and Dynamics, RWTH Aachen University \\ Mies-van-der-Rohe-Straße 1, 52074 Aachen, Germany \\ milijas@1bb.rwth-aachen.de, sakic@lbb.rwth-aachen.de,klinkel@lbb.rwth-aachen.de \\ ${ }^{2}$ Department of Engineering Mechanics and Theory of Structures, Faculty of Civil Engineering, \\ University of Belgrade \\ Bulevar kralja Aleksandra 73, 11000 Belgrade, Serbia \\ mmarinkovic@grf.bgd.ac.rs \\ ${ }^{3}$ Center for Wind and Earthquake Engineering, RWTH Aachen University \\ Mies-van-der-Rohe-Straße 1, 52074 Aachen, Germany \\ butenweg@lbb.rwth-aachen.de
}

\begin{abstract}
Masonry infills are commonly used as exterior or interior walls in reinforced concrete $(R C)$ frame structures and they can be encountered all over the world, including earthquake prone regions. Since the middle of the $20^{\text {th }}$ century the behaviour of these non-structural elements under seismic loading has been studied in numerous experimental campaigns. However, most of the studies were carried out by means of in-plane tests, while there is a lack of out-of-plane experimental investigations. In this paper, the out-of-plane tests carried out on full scale masonry infilled frames are described. The results of the out-of-plane tests are presented in terms of force-displacement curves and measured out-of-plane displacements. Finally, the reliability of existing analytical approaches developed to estimate the out-of-plane strength of masonry infills is examined on presented experimental results.
\end{abstract}

Keywords: Seismic loading, Masonry infill, Out-of-plane load, Out-of-plane strength. 


\section{INTRODUCTION}

The influence of infills on the seismic response of frame structures has long been recognised [1]. However, the issue of how the infills affect the seismic performance of an RC building is intricate as well as their exact role during an earthquake is complex and not yet clearly understood [2]. Regularly distributed infills may significantly contribute to withstand the seismic actions, as also proved during moderate and strong earthquakes, reducing the deformation demand and improving the energy dissipation capacity of the system $[3,4]$. However, regular infill distribution is not easy to be accomplished in practice. Furthermore, as the deflection of RC frame activates much stiffer infill walls that have a low drift capacity of $0.2-0.3 \%$ [5] and rather stiff and brittle in-plane response, infill panels achieve its maximum load capacity very fast which is followed by a sudden decrease of strength. Therefore, it can be concluded that infill wall increases the strength of infilled frame, but it highly decreases its ductility, which conflicts with ductile seismic design [5]. Increase of the stiffness of the overall system due to the infills leads to an increase of the natural frequencies and thus to an increase of the horizontal earthquake loads with a significantly different global vibration behaviour of the overall structure [6]. In addition to this, if the infills are irregularly arranged in plan and elevation, torsional effects can lead to additional loads with unfavourable load distributions which accelerate a failure of the infills [7,8,9]. Moreover, additional critical torsional effects may also occur over the course of the successive failure of overloaded infill elements, even if the infills are arranged in a regular manner [6]. If taking these shortcomings into account, it is not surprising that in almost every moderate to high intensity earthquake event RC frames with masonry infill walls suffered damage, in some cases even a total collapse [10]. In order to provide better understanding of the complex frame-infill interaction and its influence on overall seismic performance of structures, most experimental campaigns focused on behaviour of infilled frames under in-plane component of seismic loading.

On the other side, the performance of infilled frames under out-of-plane seismic loading component was the subject of significantly smaller number of experimental researches. In one of the first experimental investigations on out-of-plane behaviour of URM walls conducted by McDowell et al. (1956a,b) [11,12], the important arching action or arching effect was discovered. Further experimental studies on out-of-plane response of masonry infills were carried out by Dawe and Seah (1989b) [13], Angel et al. (1994) [14], Flanagan and Bennett (1999b) [15] and Di Domenico (2018) [16], among others. In the work of these authors, the parameters affecting arching action were investigated and it was concluded that infill wall built in a traditional way with a full contact to surrounding frame can achieve a several times larger out-of-plane capacity than its expected flexural capacity. In addition to this, the results showed that arching effect is mostly governed by a compressive strength of the wall, panel dimensions (slenderness), boundary conditions between the infill and the frame and stiffness of the surrounding frame. Furthermore, the development of arching or rigid body mechanism can be distinguished depending on the condition of infill-frame connections [17]. The ineffective frame-infill connections can be caused by poor quality execution as pointed out in [18] or mortar shrinkage. In more recent studies, the influence of workmanship was therefore investigated in the work of Akhoundi et al. (2020) [19]. The further investigations of out-ofplane behaviour of masonry infills appear to be inevitable after observations of damages after recent earthquake events. For instance, in the L'Aquila 2009 earthquake in Italy, out-of-plane mechanisms led to the lowest capacity of the infills, thus representing the condition of highest risk for human safety [20]. To make the matters worse, not only can the out-of-plane failure occur on upper storeys of buildings due to higher amplification of ground acceleration, but masonry infills can also suffer substantial damage due to interaction of in-plane and out-of- 
plane actions in the lower storeys of buildings. The detrimental combination of in-plane and out-of-plane loading was pronounced in recent earthquakes in L'Aquila 2009, Central Italy 2016, Lorca 2011, and Albania 2019.

The available experimental results have served as a useful basis for many researchers to propose simple analytical equations based on arching theory that can be applied in engineering practice for the estimation of out-of-plane capacity of masonry infill walls. Despite the fact that most theories agree in recognizing the aforementioned out-of-plane behaviour for the infilled frames, their results are often conflicting. In most cases this may be justified by substantially different choices in the reference experimental programs [21]. In this paper results of two experimental tests carried out on masonry infills with different boundary conditions are presented. Furthermore, analytical approaches based on arching theory are summarized and their accuracy in estimation of out-of-plane capacity is examined on test results.

\section{EXPERIMENTAL TESTS}

For the purpose of investigating the correctness of analytical expressions for out-of-plane strength of infill walls, two out-of-plane experimental tests will be used. The first test was conducted within the experimental campaign of the European research project INSYSME (Innovative systems for earthquake resistant masonry in reinforced concrete buildings) [22], whereas the second one was carried out in the scope of the project "Development of an innovative approach for decoupling infills and non load-bearing masonry walls from the main structure" [23] and represents the continuation of the research work done within the INSYSME project [22]. In this paper, only out-of-plane tests on two masonry infills are described. Test BO was carried out in the former and test $\mathrm{T} 1$ in the latter experimental campaign.

\subsection{Test specimens}

Both infill walls were constructed in a usual way of bricklaying. Bed joints were filled with thin layer mortar while head joints were made as dry joint connection without mortar. However, it has to be pointed out that in the specimen BO, the general purpose mortar was used to fill the remaining gap at the top, while in specimen T1 the execution of the top joint was carried out by a special pump in order to completely and perfectly fill the top gap with thin layer mortar. In both specimens bottom and side connections of masonry infill to the surrounding frame were made by general purpose mortar, but in the specimen BO a gap of 5 $\mathrm{cm}$ between infill and RC column was left in order to consider the case of wall having door opening along its whole height. In that sense, BO specimen presents three-sided and $\mathrm{T} 1$ specimen four-sided wall. The dimensions and mechanical characteristics of bricks, thin layer and general purpose mortar used in specimens are summarized in Table 1 and 2.

The surrounding reinforced concrete frames were designed according to DIN EN 1992-1-1 (2011) [24] and DIN EN 1998-1 (2010) [25] considering the German national annexes for ductility class L. Columns have $25 / 25 \mathrm{~cm}$ quadratic cross section with the $1.48 \%$ of longitudinal reinforcement. The percentage of transverse reinforcement in middle column section is $0.42 \%$, while there is $0.63 \%$ of transverse reinforcement in column corners. Beam was designed to have a width of $45 \mathrm{~cm}$ and height of $25 \mathrm{~cm}$ with the $1.05 \%$ of longitudinal reinforcement and $0.23 \%$ and $0.35 \%$ of transverse reinforcement in middle and corner sections, respectively. Dimensions of the frame and arrangement of reinforcement can be found in $[6,17]$. 


\begin{tabular}{|c|c|c|c|c|c|}
\hline \multicolumn{6}{|c|}{ Test BO } \\
\hline \multirow{3}{*}{$\begin{array}{l}\text { Mortar } \\
\text { ZP99 }\end{array}$} & Mortar type & \multicolumn{2}{|c|}{$\begin{array}{l}\text { Compressive } \\
\text { strength } \\
\mathrm{f}_{\mathrm{m}}\left(\mathrm{N} / \mathrm{mm}^{2}\right)\end{array}$} & \multicolumn{2}{|c|}{$\begin{array}{l}\text { Flexural tensile strength } \\
\qquad \mathrm{f}_{\mathrm{m}, \mathrm{flex}}\left(\mathrm{N} / \mathrm{mm}^{2}\right)\end{array}$} \\
\hline & Thin layer mortar & \multicolumn{2}{|c|}{15.7} & \multicolumn{2}{|c|}{3.67} \\
\hline & $\begin{array}{l}\text { General purpose } \\
\text { mortar }\end{array}$ & \multicolumn{2}{|r|}{8.9} & \multicolumn{2}{|c|}{2.47} \\
\hline \multirow{3}{*}{$\begin{array}{l}\text { Brick } \\
\text { MZ70 }\end{array}$} & $\begin{array}{l}\text { Dimensions } \\
\mathrm{L} / \mathrm{T} / \mathrm{H}(\mathrm{mm})\end{array}$ & \multicolumn{2}{|c|}{$\begin{array}{c}\text { Compressive } \\
\text { strength } \\
\mathrm{f}_{\mathrm{ck}}\left(\mathrm{N} / \mathrm{mm}^{2}\right)\end{array}$} & Voids (\%) & $\begin{array}{c}\text { Gross dry } \\
\text { density }\left(\mathrm{kg} / \mathrm{m}^{3}\right)\end{array}$ \\
\hline & $250 / 365 / 249$ & Vertical & Longitudinal & \multirow[b]{2}{*}{62.3} & \multirow[b]{2}{*}{553} \\
\hline & AHAS & 6.3 & 4.8 & & \\
\hline \multirow{2}{*}{ Masonry } & \multicolumn{2}{|c|}{$\begin{array}{c}\text { Compressive strength } \\
f_{k}\left(\mathrm{~N} / \mathrm{mm}^{2}\right)\end{array}$} & & \multicolumn{2}{|c|}{$\begin{array}{l}\text { Modulus of elasticity } \\
\qquad E_{m}\left(\mathrm{~N} / \mathrm{mm}^{2}\right)\end{array}$} \\
\hline & \multicolumn{2}{|l|}{3.1} & & \multicolumn{2}{|c|}{4870} \\
\hline
\end{tabular}

Table 1. Mean values of the material properties and strengths (Test BO, INSYSME [22])

Test T1

\begin{tabular}{|c|c|c|c|c|c|}
\hline \multirow{3}{*}{$\begin{array}{l}\text { Mortar } \\
\text { MAXIT }\end{array}$} & Mortar type & \multicolumn{2}{|c|}{$\begin{array}{l}\text { Compressive } \\
\text { strength } \\
\mathrm{f}_{\mathrm{m}}\left(\mathrm{N} / \mathrm{mm}^{2}\right)\end{array}$} & \multicolumn{2}{|c|}{$\begin{array}{l}\text { Flexural tensile strength } \\
\mathrm{f}_{\mathrm{m}, \mathrm{flex}}\left(\mathrm{N} / \mathrm{mm}^{2}\right)\end{array}$} \\
\hline & Thin layer mortar & \multicolumn{2}{|c|}{12.8} & \multicolumn{2}{|r|}{2.4} \\
\hline & $\begin{array}{l}\text { General purpose } \\
\text { mortar }\end{array}$ & \multicolumn{2}{|r|}{16} & \multicolumn{2}{|r|}{2.4} \\
\hline \multirow{3}{*}{$\begin{array}{l}\text { Brick } \\
\text { Thermo } \\
\text { plan } \\
\text { SX10 }\end{array}$} & $\begin{array}{l}\text { Dimensions } \\
\mathrm{L} / \mathrm{T} / \mathrm{H}(\mathrm{mm})\end{array}$ & \multicolumn{2}{|c|}{$\begin{array}{c}\text { Compressive } \\
\text { strength } \\
\mathrm{f}_{\mathrm{ck}}\left(\mathrm{N} / \mathrm{mm}^{2}\right)\end{array}$} & Voids (\%) & $\begin{array}{c}\text { Gross dry } \\
\text { density }\left(\mathrm{kg} / \mathrm{m}^{3}\right)\end{array}$ \\
\hline & $247 / 300 / 249$ & Vertical & Longitudinal & \multirow[b]{2}{*}{56} & \multirow[b]{2}{*}{600} \\
\hline & & 9.57 & 1.67 & & \\
\hline \multirow{2}{*}{ Masonry } & \multicolumn{2}{|c|}{$\begin{array}{c}\text { Compressive strength } \\
f_{k}\left(\mathrm{~N} / \mathrm{mm}^{2}\right)\end{array}$} & \multicolumn{3}{|c|}{$\begin{array}{l}\text { Modulus of elasticity } \\
\qquad E_{m}\left(\mathrm{~N} / \mathrm{mm}^{2}\right)\end{array}$} \\
\hline & \multicolumn{2}{|c|}{$2.68 *$} & \multicolumn{3}{|c|}{$2680 *$} \\
\hline
\end{tabular}

Table 2. Mean values of the material properties and strengths (Test T1, Development of an innovative approach for decoupling infills and non load-bearing masonry walls from the main structure [23])

*Values calculated according to Eurocode 6 [37] 


\subsection{Test setup and loading protocols}

The test setup for specimen BO was specifically constructed for the experimental tests within the INSYSME project [22]. Vertical force of $200 \mathrm{kN}$ per column was applied with the vertical hydraulic jacks before the application of out-of-plane load and kept constant during the whole test. Air bags for out-of-plane loading were placed between the stiff supporting panel and infill wall thus allowing only the deformation of infill wall. Detailed description of the test setup for specimen BO can be found in [6, 17].

The test setup for specimen T1 was purposely designed for the experimental tests within the project "Development of an innovative approach for decoupling infills and non loadbearing masonry walls from the main structure" [23]. Vertical force of $200 \mathrm{kN}$ per column was applied by one-way hydraulic actuators connected to a pressure accumulator to ensure near constant pressure during the test. A special harness is used for these actuators, which consists of two rods per column, a steel beam at the top and specially designed steel angles connected to the frame at the foundation beam. After the application of vertical load, the outof-plane load is imposed to the infill by four airbags. The airbags are placed between the infill and a wooden reaction wall at the back of the wall.

\subsection{Experimental results}

\subsubsection{Test BO}

In test BO masonry infill wall supported on three sides with one free vertical edge was subjected to out-of-plane loading applied in four cycles. On Figure 1 load-displacement curve is presented. It shows that the specimen achieved maximum resistance of about $170 \mathrm{kN}$ which corresponds to a uniformly distributed load of about $24 \mathrm{kN} / \mathrm{m}^{2}$. In first two loading cycles the out-of-plane displacements were relatively small due to stable arching action. However, in the third load cycle at the load level of about $24 \mathrm{kN} / \mathrm{m}^{2}$ sudden friction failure occurred in the top joint between infill and the upper beam of the frame which triggered the tilting of the wall. In addition to this, splitting and overloading of the bricks in the uppermost infill row caused the loss of boundary condition at the top. The substantial increase of displacements was observed at the infill free edge, especially at the top (Figure 2).

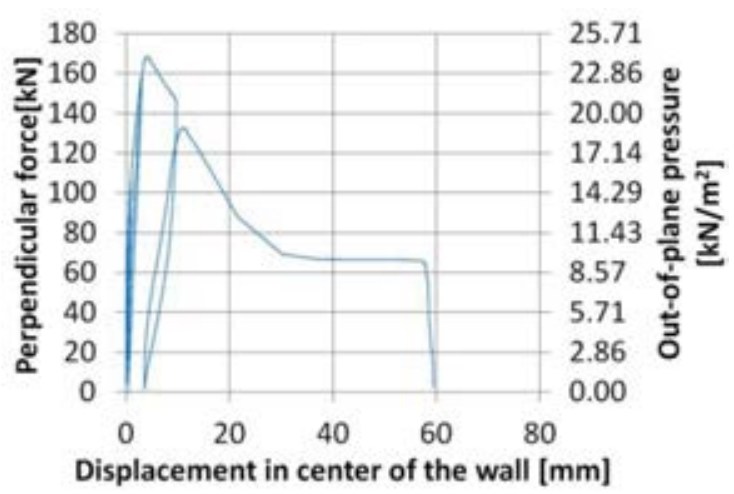

Figure 1. Force-displacement curve for out-of-plane loading of the test BO (Marinković, 2018) [17]

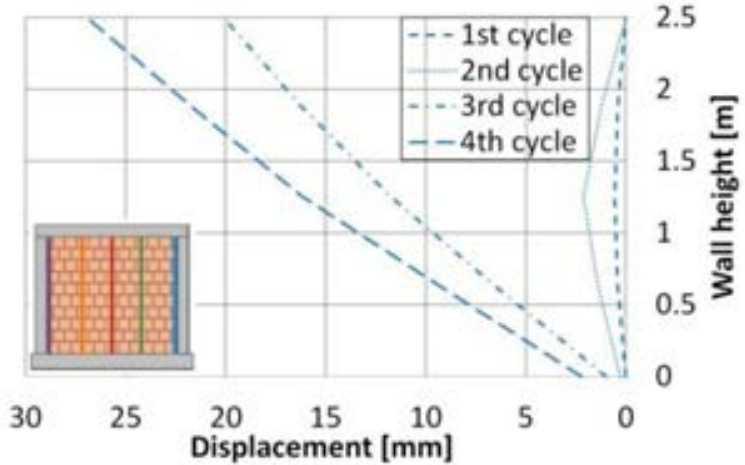

Figure 2. Side view of the out-of-plane displacements of the vertical section at the free edge of the wall in test BO (Marinković, 2018) [17] 
In the final load cycle the splitting of the bricks at the wall base occurred too and thus destroyed the bottom boundary condition. As a consequence, the formation of arching effect was prevented. Right side of the wall moved as a rigid body until the occurrence of cracking through head joints in the central part of infill (Figure 3). The measured out-of-plane displacements at the end of the fourth cycle are presented in Figure 4.

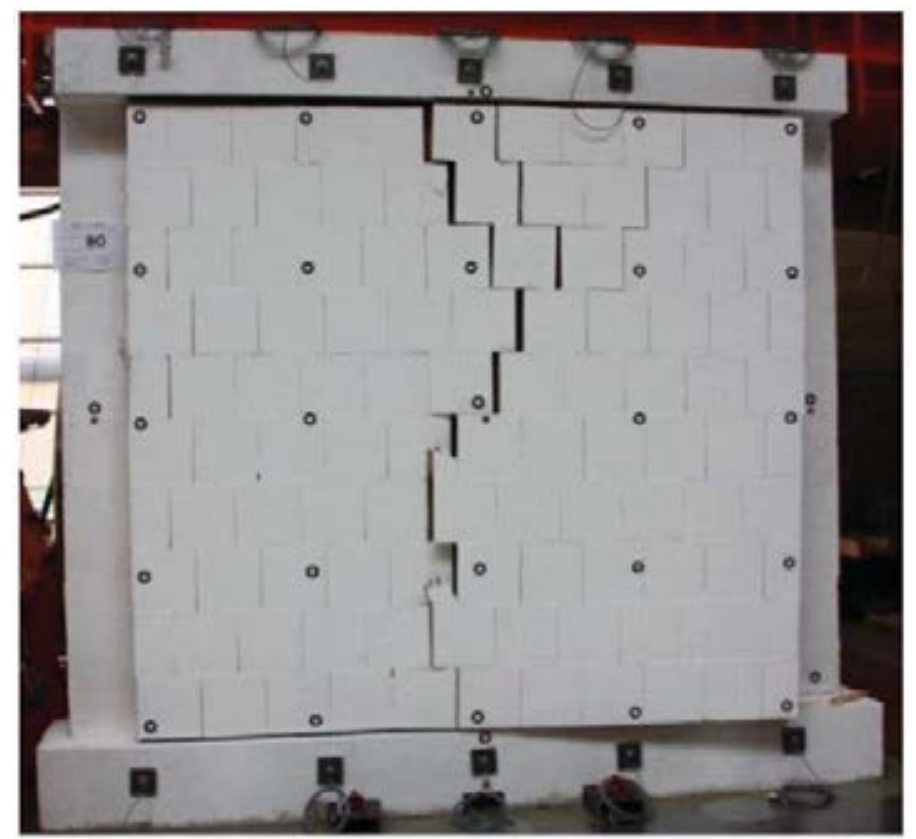

Figure 3. Damage to the wall at the end of the test BO (Butenweg et al. 2019) [6]

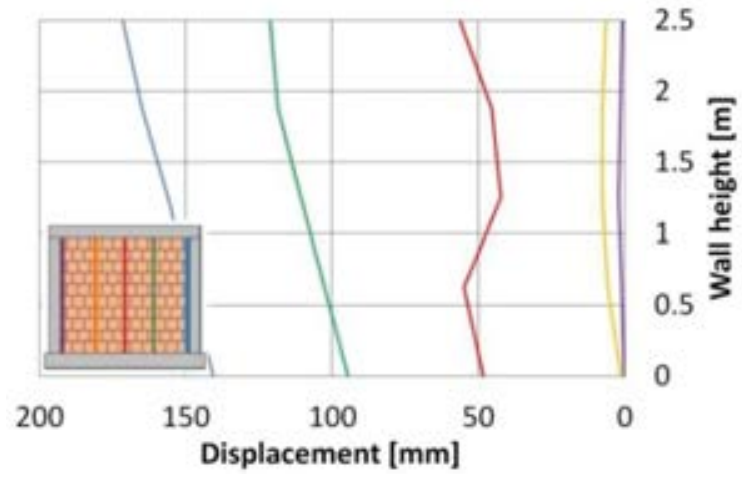

Figure 4. Side view of the out-of-plane displacements at the end of the fourth loading cycle of the test BO (Butenweg, et al. 2019) [6]

\subsubsection{Test T1}

In test $\mathrm{T} 1$ four side supported masonry infill wall was subjected to out-of-plane loading applied in two cycles. On Figure 5 load-displacement curve is presented. The specimen was able to withstand the total out-of-plane force of $175.6 \mathrm{kN}$ which corresponds to $25.2 \mathrm{kN} / \mathrm{m}^{2}$ of uniform load. The wall deflection in the first load cycle indicated the formation of two-way arching mechanism (Figures 6 and 7). The out-of-plane displacements in this loading phase were quite small, not exceeding $2 \mathrm{~mm}$. With the further application of the out-of-plane loading in the second cycle, the out-of-plane displacements increased. Central vertical and horizontal strips deflected more than the outer strips (Figure 8) thus confirming the presence of strong two-way arching action. Although there were no visible signs of any substantial 
damage to the masonry infill, at the load level of about $25 \mathrm{kN} / \mathrm{m}^{2}$ the part of the infill abruptly fell out. Due to strong and undamaged connections at the top and bottom of the infill wall, the rotation between topmost row of bricks and upper beam and lowermost row of bricks and bottom beam was limited at higher load levels. Due to this, compressive stresses increased faster in the compressive thrust near the arc supports. The thin and brittle webs of bricks in compression zones of arc supports crushed under excessive compressive stresses which led to the expulsion of the part of the wall and complete failure of specimen (Figure 9).

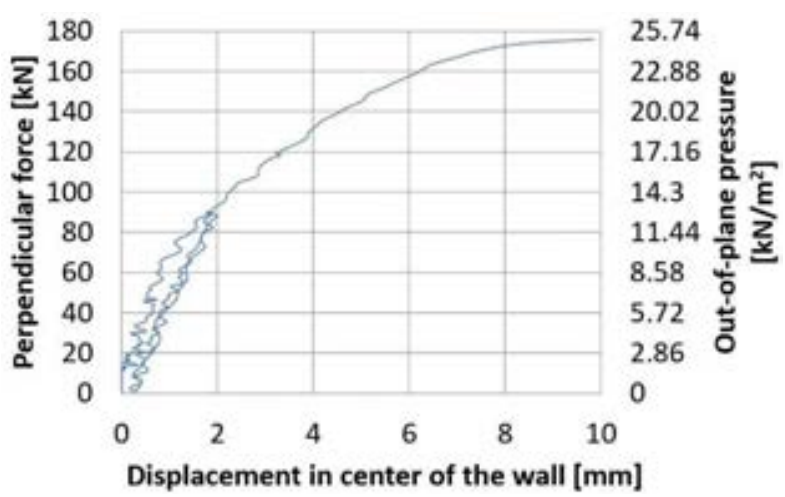

Figure 5. Force - displacement curve for out-of-plane loading of the test $\mathrm{T} 1$

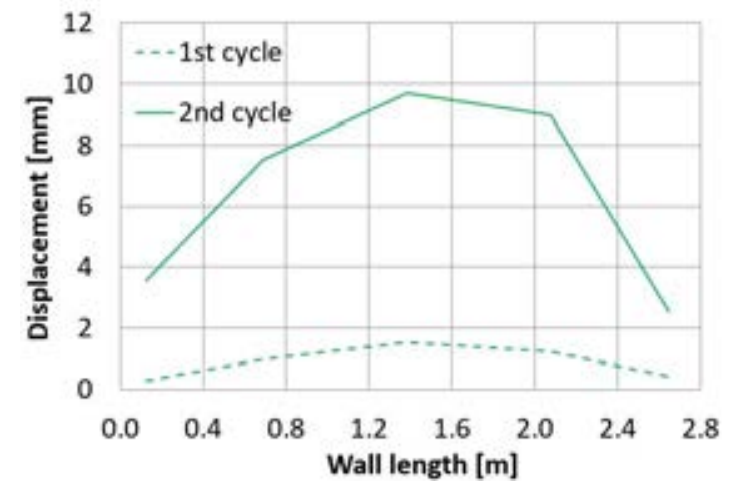

Figure 7. Top view of the out-of-plane displacements of the central horizontal section of the test T1

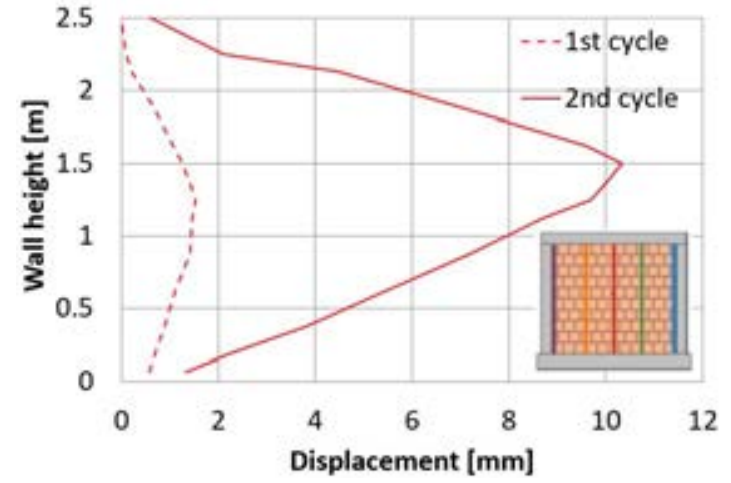

Figure 6. Side view of the out-of-plane displacements of the central vertical section of the test $\mathrm{T} 1$

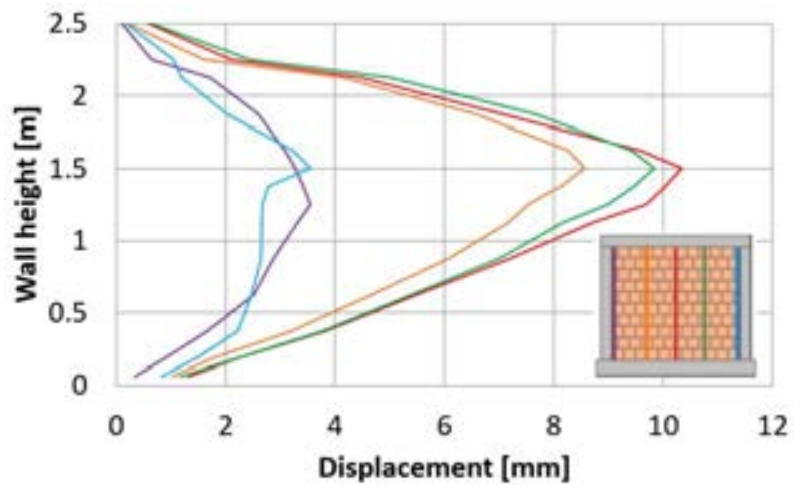

Figure 8. Deflection of vertical strips in the end of second loading cycle of test $\mathrm{T} 1$

Even after the collapse of the infill, thin layer mortar at the top remained intact and strongly connected to the top beam and rest of the bricks in the uppermost row of the infill. Namely, during the inspection of specimen after the test, it was noticed that vertical holes of bricks were filled with a huge amount of thin layer mortar since it had been falling into narrow voids during its application by a special pump. 


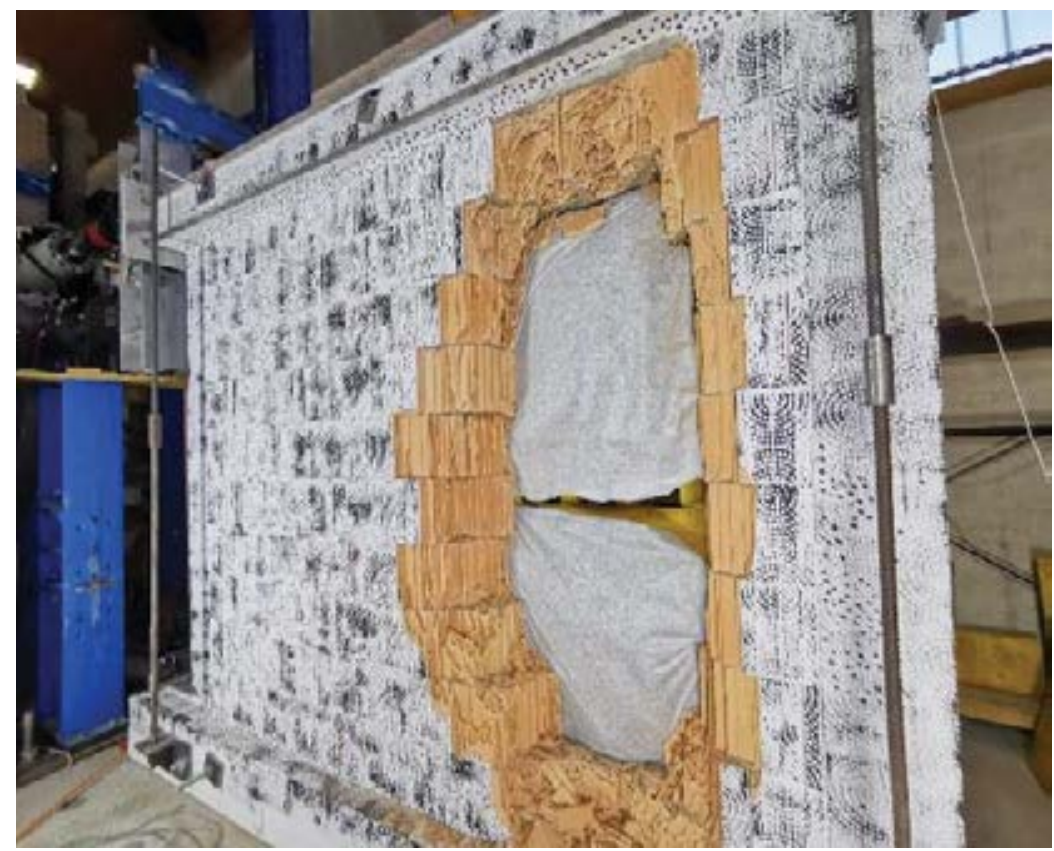

Figure 9. Infill wall after the collapse (test T1)

\section{SUMMARY OF ANALYTICAL APPROACHES ESTIMATING OUT-OF-PLANE CAPACITY}

In the case of earthquake loading, masonry infills are subjected to out-of-plane loads due to the mass and inertia of the wall. Since the out-of-plane loads can be approximated as uniformly distributed, out-of-plane capacity of masonry infills is usually defined as the uniform lateral pressure causing the collapse of the wall. Some of the first approaches used for estimation of out-of-plane capacity were derived from Timoshenko theory (Timoshenko and Woinowsky-Krieger,1959) [26]:

$$
q=\frac{f_{m t}}{6 \beta_{1}\left(\frac{h}{t}\right)^{2}}
$$

The governing parameter is a tensile strength $f_{m t}$ of linearly elastic, homogeneous and isotropic material, while $\beta_{1}$ is a coefficient depending on the aspect ratio of the panel and its restrain conditions. In the other methods two-way action was taken into account by using yield line analysis (Hendry, 1973; Hendry and Kheir, 1976) [27,28]. In the approach proposed by Haseltine (Haseltine, 1976; Haseltine et al. 1977) [29,30] the governing parameter is flexural tensile strength $f_{x k 2}$ orthogonal to the bed joints:

$$
q=\frac{f_{x k 2}}{6 a\left(\frac{h}{t}\right)^{2} \gamma_{m} \gamma_{f}}
$$

Panel shape and restraint conditions are taken into account by bending coefficient $a, \gamma_{m}$ is safety coefficient related to the materials and $\gamma_{f}$ is an importance factor.

These approaches that considered tensile or flexural strength as the governing parameter appeared to be limited in the prediction of ultimate out-of-plane capacity and only capable of estimation of masonry cracking. However, experiments [13-16] showed that membrane forces appear in the wall due to deformation of the wall after cracking, thus proving that the arching action is a predominant resisting mechanism. 
McDowell et al. (1956a,b) [11,12] were the first to propose calculation of out-of-plane capacity of masonry walls considering one-way arching action. Instead of flexural or tensile strengths which were used in preceding approaches, they incorporated compressive strength of masonry into their formulation. In the researches that followed this one, two-way arching action was also considered in analytical models.

After verification of their postcracking analysis program on the results of out-of-plane tests on concrete masonry infills surrounded by steel frames, Dawe and Seah (1989b) [13] conducted an extensive parametric study in order to determine the most important parameters affecting out-of-plane capacity of masonry infills. Based on the results of this study they developed empirical relationship for the calculation of out-of-plane capacity of masonry infills:

$$
q=0.8 f_{m}^{\prime 0.75} t^{2}\left(\frac{\alpha}{l^{2.5}}+\frac{\beta}{h^{2.5}}\right)
$$

where $f_{m}^{\prime}$ is masonry compressive strength (MPa), $t$ is the infill thickness $(\mathrm{mm}), h$ is the infill height $(\mathrm{mm}), l$ is the infill length $(\mathrm{mm})$. Parameter $\alpha$ takes into account the relative stiffness of the bounding column, while parameter $\beta$ takes into account the relative stiffness of the bounding beam. The parameters should be calculated according to the equations below, distinguishing the case of four-sided wall (eq. 4 and 5) or three-sided wall with the gap at the top (eq. 6 and 7):

$$
\begin{gathered}
\alpha=\frac{1}{h}\left(E I_{c} h^{2}+G_{c} J_{c} t h\right)^{0.25} \leq 50 \\
\beta=\frac{1}{l}\left(E I_{b} l^{2}+G_{b} J_{b} t l\right)^{0.25} \leq 50 \\
\alpha=\frac{1}{h}\left(E I_{c} h^{2}+G_{c} J_{c} t h\right)^{0.25} \leq 75 \\
\beta=0
\end{gathered}
$$

In the equations (4-7), $E$ is the modulus of elasticity of frame material (MPa),$I_{c}$ is the moment of inertia in the plane of the infill of the column $\left(\mathrm{mm}^{4}\right), I_{b}$ is the moment of inertia in the plane of the infill of the beam $\left(\mathrm{mm}^{4}\right), G$ is shear modulus (MPa), $J_{c}$ is torsional constant of the column $\left(\mathrm{mm}^{4}\right), J_{b}$ is torsional constant of the beam $\left(\mathrm{mm}^{4}\right)$.

Angel et al. (1994) [14] developed analytical model based on arching action of an infill strip spanning between two rigid supports. The authors distinguished two failure modes depending on the slenderness ratio; for the infills with $h / t$ values lower than determined critical slenderness ratio crushing at arc boundaries is expected to occur, otherwise the snap through the panel may appear. In addition to this, they considered the effects of previous inplane damage, flexibility of the confining frame and panel slenderness ratio on the out-ofplane behaviour. Therefore, the ultimate out-of-plane strength could be estimated by the following equation:

$$
q=R_{1} R_{2} \frac{2 f_{m}^{\prime} \lambda}{h / t}
$$


where $t$ is the thickness of the wall $(\mathrm{mm}), h$ is the height of the wall $(\mathrm{mm}), l$ is the length of the wall $(\mathrm{mm}), f_{m}^{\prime}$ is the compressive strength of masonry infill $(\mathrm{MPa})$ and $\lambda$ is the dimensionless parameter that can be calculated according to equation (9) proposed by Flanagan and Bennett (1999c) [31]. Coefficient $R_{l}$ is the reduction factor that considers previous in-plane damage and coefficient $R_{2}$ accounts for the flexibility of the confining frames in the case of edge location of the infill, meaning that the panel is located in the exterior bay or the uppermost story. Coefficients $R_{1}$ and $R_{2}$ can be calculated by using the equations (10-12).

$$
\begin{gathered}
\lambda=0.154 \exp \left(-0.0985 \frac{h}{t}\right) \\
R_{1}=\left(1.08-0.015 \frac{h}{t}-0.00049\left(\frac{h}{t}\right)^{2} 0.000013\left(\frac{h}{t}\right)^{3}\right)^{\frac{\Delta}{2 \Delta_{c r}}} \\
\text { for } \frac{\Delta}{2 \Delta_{c r}} \geq 0.5 \\
R_{2}=0.357+2.49 E I 10^{-14} \text { for } E I<25.8310^{12} \\
R_{2}=1 \text { for } E I \geq 25.8310^{12} \\
E I=E \min \left\{I_{b} ; I_{c}\right\}
\end{gathered}
$$

where $\Delta$ represents the maximum in-plane inter-story drift that panel has experienced and $\Delta_{\mathrm{cr}}$ is the cracking drift, $E I$ is the flexural stiffness corresponding to the smallest member of the confining frame at the panel edge with no continuity.

In the thorough study of Flanagan and Bennett (1999c) [31], the performance of analytical methods proposed by Dawe and Seah (1989b) [13] and Angel et al. (1994) [14] in estimating the out-of-plane strength of masonry infills was examined on 36 experimental tests carried out by Thomas (1953) [32], Anderson and Bright (1976) [33], Dawe and Seah (1989b) [13], Fricke et al. (1992) [34], Frederiksen (1992) [35], Angel et al. (1994) [14] and Flanagan and Bennett (1999b) [15]. The empirical method proposed by Dawe and Seah (1989b) [13] provided the best prediction of out-of-plane capacity, but with consistent overestimation. Therefore, Flanagan and Bennett (1999c) [31] modified the constant in (3) from 0.8 to 0.73 and proposed the following equation for the calculation of out-of-plane capacity of masonry infills:

$$
q=0.73 f_{m}^{\prime 0.75} t^{2}\left(\frac{\alpha}{l^{2.5}}+\frac{\beta}{h^{2.5}}\right)
$$

where $f_{m}^{\prime}$ is masonry compressive strength $(\mathrm{MPa}), h$ is the height of the wall $(\mathrm{mm}), l$ is the length of the wall $(\mathrm{mm})$. The authors recommend the application of the modified thickness of the wall $t_{2}=h / 8$ if the infill walls slenderness ratio is less than $8(h / t<8)$. Parameters $\alpha$ and $\beta$ can be calculated according to the following equations:

$$
\alpha=\frac{1}{h}\left(E I_{c} h^{2}\right)^{0.25} \leq 50
$$




$$
\beta=\frac{1}{l}\left(E I_{b} l^{2}\right)^{0.25} \leq 50
$$

In the equations (15-16), $E$ is the modulus of elasticity of frame material $(\mathrm{MPa}), I_{c}$ is the moment of inertia in the plane of the infill of the column $\left(\mathrm{mm}^{4}\right), I_{b}$ is the moment of inertia in the plane of the infill of the beam $\left(\mathrm{mm}^{4}\right)$. The authors neglected the influence of torsional stiffness on the out-of-plane capacity of masonry infills which was considered in the method of Dawe and Seah (1989b) [13].

In Eurocode 8 (2004) [36] it is stated that particular attention should be paid to masonry panels with a slenderness ratio greater than 15, but there are no specific design recommendations for the calculation of out-of-plane strength of masonry infills. However, in Eurocode 6 (2005) [37] one-way arching action is assumed as lateral loads resisting mechanism of URM wall and the out-of-plane capacity of URM walls can be calculated according to the equations:

$$
q=f_{m}^{\prime}(t / a)^{2} \text { for } t / a<20
$$

where $f_{m}^{\prime}$ is compressive strength of masonry infill (MPa), $t$ is the thickness of the wall $(\mathrm{mm})$, $h$ is the height of the wall $(\mathrm{mm}), l$ is the length of the wall $(\mathrm{mm})$ and $a$ is taken as:

$$
\mathrm{a}=\max \{h ; l\}
$$

Based on analytical investigation of the behaviour of masonry infills supported on two sides under transverse loading, Moghaddam and Goudarzi (2010) [38] developed semiempirical relationship between out-of-plane capacity of masonry infills and rigidity of the bounding frame, properties of the masonry material and slenderness ratio. Two failure modes are distinguished: boundary crushing $\left(q_{c r}\right)$, when the crushing takes place at the supports of the infill and transverse instability $\left(q_{\max }\right)$, which occurs due to the large transverse deflection of the infill. The out-of-plane capacity corresponds to the smaller of two values:

$$
\begin{gathered}
\mathrm{q}=\min \left\{q_{c r} ; q_{\max }\right\} \\
q_{c r}=\left(\frac{0.85 f_{m}^{\prime}}{(h / t)^{2}}-\left(0.12+\frac{0.045}{\alpha}\right) \frac{f_{m}^{\prime 2}}{E_{m}}\right) \\
q_{\max }=\left(\frac{0.18 E_{m}}{\left(0.12+\frac{0.045}{\alpha}\right)\left(\frac{h}{t}\right)^{4}}\right) \\
\alpha=384 \frac{E I_{b} h}{E_{m} t l^{4}}
\end{gathered}
$$

where $f_{m}^{\prime}$ is compressive strength of masonry infill (MPa), $E$ is Young's modulus of frame material $(\mathrm{MPa}), E_{m}$ is Young's modulus of masonry infill wall $(\mathrm{MPa}), t$ is the thickness of the wall $(\mathrm{mm}), h$ is the height of the wall $(\mathrm{mm}), l$ is the length of the wall $(\mathrm{mm})$.

Morandi et al. (2013) [39] proposed the equation for the calculation of ultimate out-ofplane capacity of the masonry infill based on the recommendations from Eurocode 6 (2005) 
[37]. Besides the contribution of the arching mechanism to out-of-plane capacity of the infill, the presence of vertical reinforcement in the masonry infill may also be taken into account:

$$
q=0.72\left(\frac{t}{h}\right)^{2} f_{m}^{\prime}+7.2 \frac{t}{l h^{2}} A_{s} f_{y}
$$

where, $f_{m}^{\prime}$ is the compressive strength of masonry infill (MPa), $t$ is the thickness of the wall $(\mathrm{mm}), h$ is the height of the wall $(\mathrm{mm}), l$ is the length of the wall $(\mathrm{mm}), A_{s}$ is the total cross sectional area of the vertical reinforcement in tension $\left(\mathrm{mm}^{2}\right)$ and $f_{y}$ is the reinforcement yield strength $(\mathrm{MPa})$. However, the authors stated that the equation refers to the masonry infills which did not suffer any previous in-plane damage.

Unsatisfied with the relialibity of existing formulations for prediction of out-of-plane strength, first cracking load and displacement at the collapse of masonry infills, Ricci et al. (2018) [40] proposed semi-empirical approach that defines the characteristic points of a trilinear out-of-plane force-displacement curve based on geometric and mechanical properties of infills. They applied a linear least square regression in their work and defined the cracking and peak out-of-plane uniformly distributed loads $\mathrm{q}_{\text {crack }}$ and $\mathrm{q}_{\max }$, respectively:

$$
\begin{aligned}
q_{\text {crack }} & =0.31 f_{m}^{\prime 0.05} \frac{t}{h^{2.66}} \\
q_{\text {max }} & =1.95 f_{m}^{\prime 0.35} \frac{t^{1.59}}{h^{2.96}}
\end{aligned}
$$

where $t$ is the thickness of the wall (m), $h$ is the height of the wall (m) and $f_{m}^{\prime}$ is the compressive strength of masonry infill (MPa).

\section{ESTIMATION OF OUT-OF-PLANE CAPACITY}

Results of described experimental tests are used to examine the precision of predicting outof-plane capacity of masonry infills by means of simple analytical equations summarized in Chapter 3 of this paper. It has to be pointed out that only methods based on arching theory were considered. Figure 10 and Table 3 show the comparison of predicted and experimental values from test $\mathrm{BO}$, whereas the comparison of analytical and experimental results for test $\mathrm{T} 1$ is presented in Figure 11 and Table 4.

From Figure 10 and Table 3, it could be concluded that only estimation by method of Flanagan and Bennett (1999c) [31] is in good agreement with experimental result of test BO. This could be explained with the fact that this semi-empirical analytical approach could be applied to walls with a gap at one side by setting parameter $\alpha$ that accounts for stiffness of columns to 0. The similar semi-empirical equation proposed by Dawe and Seah (1989b) [13] overestimates the actual capacity $34 \%$, although it also considers case of three-sided BO wall by neglecting columns stiffness. However, it is surprising that predictions calculated according to Angel et al. (1994) [14], Eurocode 6 (2005) [37], Moghaddam and Goudrazi (2010) [38], Morandi et al. (2013) [39] substantially overestimate the actual capacity of BO specimen as their theories are based on one-way arching which was the major resisting mechanism in test BO until the occurrence of tilting. Such a significant discrepancy between experimental result and out-of-plane strengths predicted by these analytical approaches might be due to the loss of boundary conditions at the top and bottom of the $\mathrm{BO}$ wall which led to the inhibition of the arching action and therefore moving of the infill out of RC frame plane. The reason for overestimation of actual capacity of specimen BO by semi-empirical approach 
of Ricci et al. (2018) [40] could be that it was based on regression that produces satisfactory ratio of predicted to experimental values of masonry infills supported on four sides.

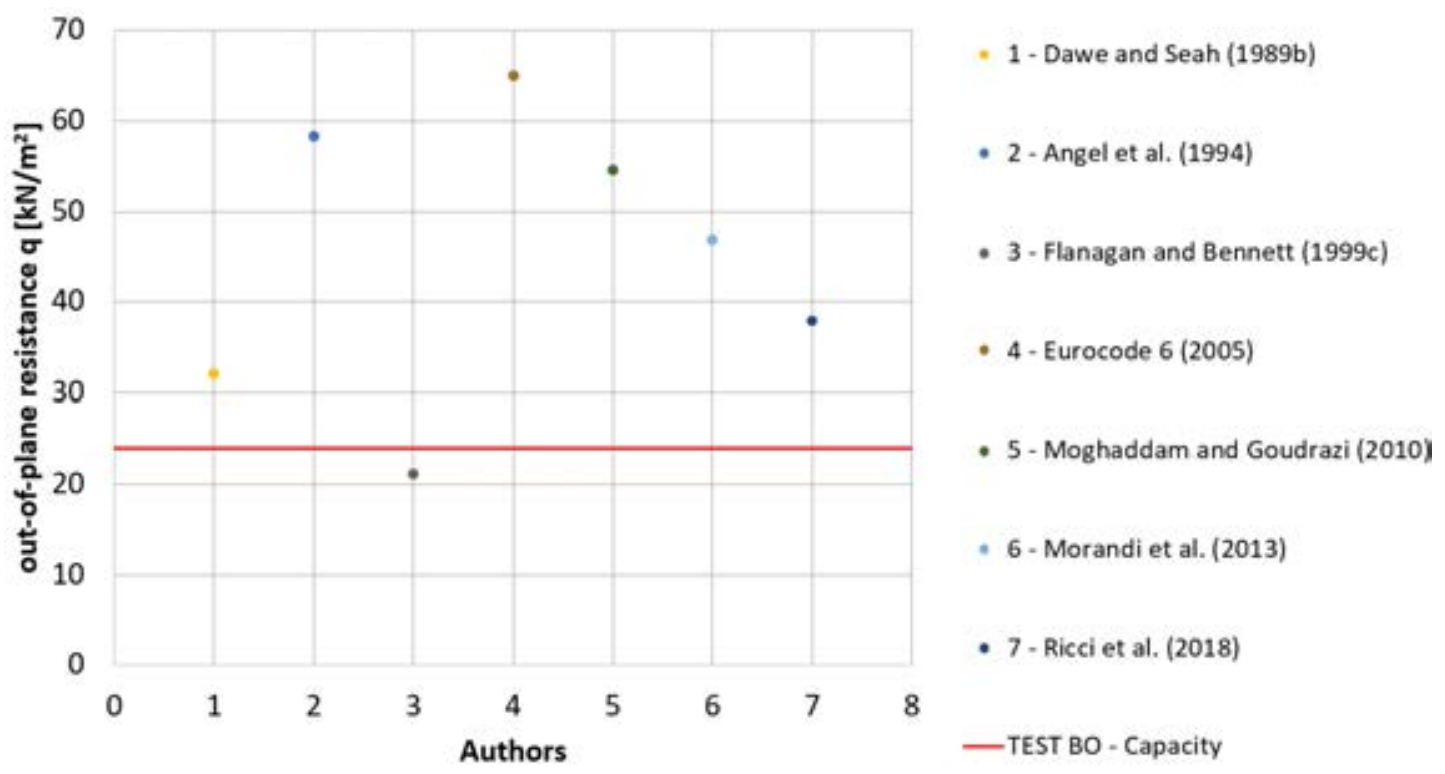

Figure 10. Comparison of calculated out-of-plane capacities with actual capacity in test BO

\begin{tabular}{|c|c|c|}
\hline Author & qpred [kN/m $\left.{ }^{2}\right]$ & qpred / q exp \\
\hline Dawe and Seah (1989b) [13] & 32.06 & 1.34 \\
\hline Angel et al. (1994) [14] & 58.29 & 2.43 \\
\hline Flanagan and Bennett (1999c) [31] & 21.08 & 0.88 \\
\hline Eurocode 6 (2005) [37] & 65.03 & 2.71 \\
\hline Moghaddam and Goudrazi (2010) [38] & 54.54 & 2.27 \\
\hline Morandi et al. (2013) [39] & 46.83 & 1.95 \\
\hline Ricci et al. (2018) [40] & 37.84 & 1.58 \\
\hline
\end{tabular}

Table 3. Comparison of calculated out-of-plane capacities with actual capacity in test BO

On the other side, perhaps due to the same reason explained above, in the case of masonry infill restrained on four sides analyzed in test $\mathrm{T} 1$ the best estimation of out-of-plane capacity is achieved by semi-empirical approach proposed by Ricci et al. (2018) [40]. Among two formulations that take into account two-way arching effects, Flanagan and Bennett (1999c) [31] appeared to be closer to actual out-of-plane strength of specimen T1 due to the lower numerical constant in their equation (14) than in the equation (3) of Dawe and Seah (1989b) [13]. The small discrepancy between out-of-plane capacities predicted by Angel et al. (1994) [14] and Morandi et al. (2013) [39] and experimentally measured out-of-plane resistance of four-sided specimen in test $\mathrm{T} 1$ needs to be interpreted cautiously since the contribution of horizontal arching was not considered in the approaches of these two authors, but it is pronounced in specimen in test T1. Other two approaches developed assuming one-way arching (Eurocode 6 (2005) [37] and Moghaddam and Goudrazi (2010) [38]) overestimated the actual out-of-plane strength of T1 specimen with an error of about $25 \%$. 


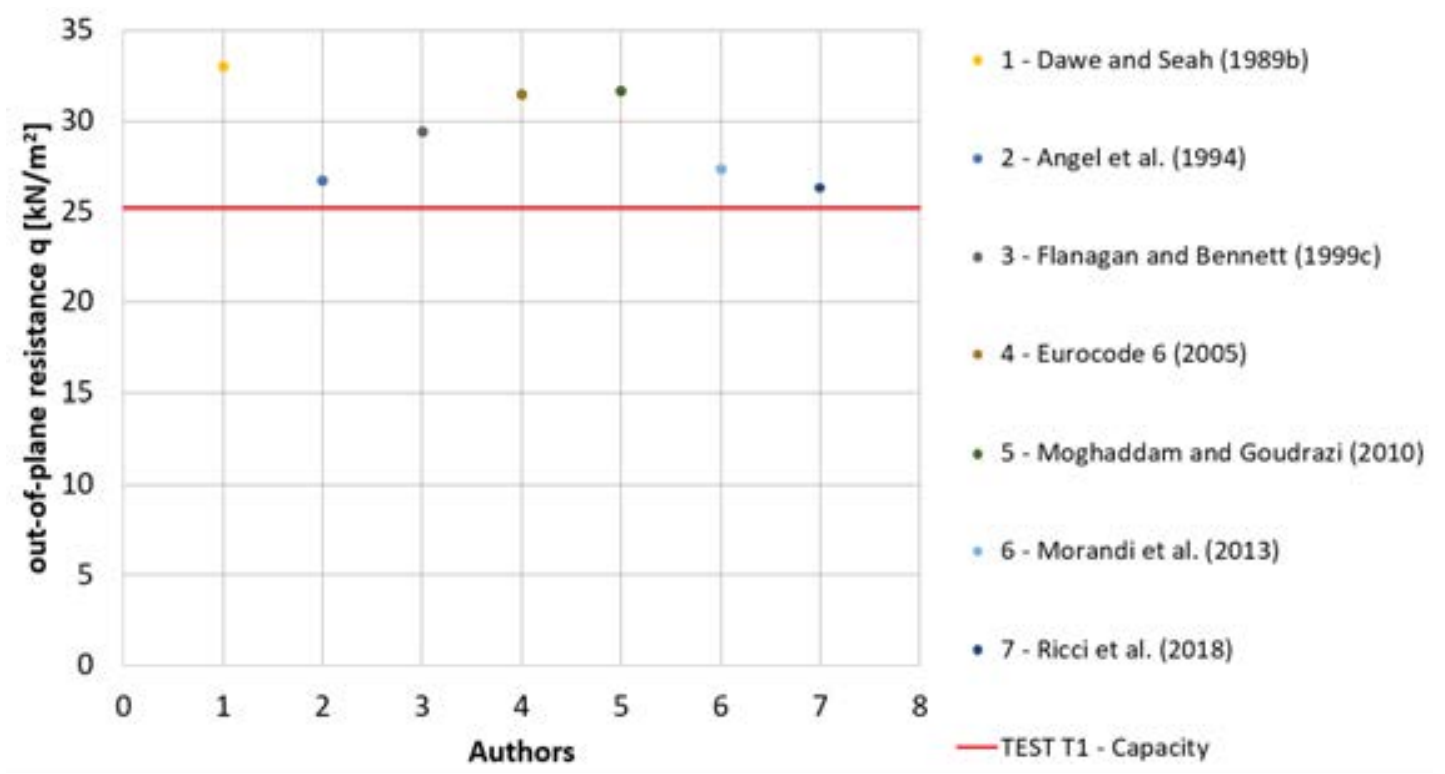

Figure 11. Comparison of calculated out-of-plane capacities with actual capacity in test T1

\begin{tabular}{|c|c|c|}
\hline Author & qpred [kN/m $\left.{ }^{2}\right]$ & qpred $/$ qexp \\
\hline Dawe and Seah (1989b) [13] & 33.01 & 1.31 \\
\hline Angel et al. (1994) [14] & 26.67 & 1.06 \\
\hline Flanagan and Bennett (1999c) [31] & 29.39 & 1.17 \\
\hline Eurocode 6 (2005) [37] & 31.44 & 1.25 \\
\hline Moghaddam and Goudrazi (2010) [38] & 31.65 & 1.26 \\
\hline Morandi et al. (2013) [39] & 27.35 & 1.09 \\
\hline Ricci et al. (2018) [40] & 26.32 & 1.04 \\
\hline
\end{tabular}

Table 4. Comparison of calculated out-of-plane capacities with actual capacity in test T1

This short study shows that Flanagan and Bennett (1999c) [31] can quite accurately predict the out-of-plane capacity of three-sided masonry infill in test BO since ratio of predicted to experimental value is 0.88. As expected, estimation of Dawe and Seah (1989b) [13] is less conservative than Flanagan and Bennett (1999c) [31] as predicted to experimental ratio is 1.34. The other approaches overestimate the actual strength of specimen BO more than 1.5 times. The lowest ratio of predicted to experimental out-of-plane capacity $\left(q_{\text {pred }} / q_{\exp }=1.04\right)$ of four-sided masonry infill in test T1 is achieved by application of semi-empirical approach by Ricci et al. (2018) [40], while calculation according to Dawe and Seah (1989) [13] leads to the largest ratio of 1.31 .

\section{CONCLUSIONS}

This paper deals with investigation of out-of-plane behaviour of masonry infills. Firstly, full scale out-of-plane experimental tests carried out in the scope of two related experimental campaigns are described. The out-of-plane response of masonry infills with different boundary conditions was investigated in the tests. Three side supported wall resisted the imposed out-of-plane loading by stable vertical arching action. However, due to loss of boundary conditions at the top and bottom whole wall started to move out of RC frame plane, with largest deflections at the free edge. The out-of-plane displacements of infill were relatively small until the sudden loss of top joint connection which prevented the arching action and triggered the wall tilting. On the other side, in the four side supported infill wall 
pronounced two-way arching action was established. The out-of-plane displacements were relatively small until the explosion-like collapse of the wall. Unlike the first test, frame-infill connections did not suffer any damage and remained in good condition thanks to perfectly executed, but difficult and time demanding filling of the gap at the top with thin layer mortar by pump. Due to this, the rotation was shifted from top connection one joint lower. Additionally, thin brick webs crushed under high compressive stresses induced by arching action. As a consequence, part of the infill defined by head joints and crushed bricks fell out of wall plane.

It has to be pointed out that achieved out-of-plane capacities of both infills represent a significant level of seismic safety in terms of out-of-plane failure. This can be explained by favourable slenderness ratios $(\mathrm{h} / \mathrm{t}=6.9$ in test $\mathrm{BO} ; \mathrm{h} / \mathrm{t}=8.4$ in test $\mathrm{T} 1)$ and relatively low weight of hollow clay bricks resulting in low mass of the considered walls (about $1.5 \mathrm{t}$ in test $\mathrm{BO} ; 1.3 \mathrm{t}$ in test T1). However, the results show a clear dependency of out-of-plane response on the quality of execution of frame-infill joints, especially at the top.

Furthermore, the existing analytical approaches for prediction of out-of-plane strength are summarized. The importance of discovery and consideration of arching effect in the evaluation of out-of-plane strength of masonry infills is explained and various parameters affecting arching mechanism are discussed.

In the end a short study was conducted with the aim to test the reliability of analytical equations proposed in the literature on presented experimental results. The out-of-plane capacity of three-sided panel investigated in test BO was fairly well predicted by analytical equation of Flanagan and Bennett (1999c) [31], while Dawe and Seah (1989b) [13] overestimated the experimental value, but with smaller error in comparison to predictions of other approaches. The recommendation from Ricci et al. (2018) [40] was the most precise in the estimation of out-of-plane strength of four-sided panel in test T1. Out-of-plane capacities of specimen T1 calculated according to equations proposed by Angel et al. (1994) [14] and Morandi et al. (2013) [39] are also in good agreement with the experimental value, but the results need to be studied with special attention as these two approaches were not developed under consideration of two-way arching action which is pronounced in test T1. If taking average value of predicted to experimental ratio from both experimenal tests into account, the method proposed by Flanagan and Bennett (1999c) [31] seems to be applicable in prediction of out-of-plane strengths of both three-sided and four-sided infills. However, the larger experimental database should be considered in order to determine the analytical equation with best fitting to experimental results. In addition to this, the important aspect of the interaction between in-plane and out-of-plane seismic actions should be investigated in the future experimental studies in order to provide more realistic evaluation of out-of-plane capacity of masonry infills. As most of the analytical approaches do not consider the influence of inplane loading on the out-of-plane strength and thus considerably overestimate the out-ofplane resistance of masonry infills, more work on the formulation that accounts for reduction of out-of-plane capacity due to in-plane damage should be carried out.

\section{ACKNOWLEDGEMENTS}

The authors would like to acknowledge the support from the "Institut für Ziegelforschung Essen e.V" and express their special thanks to Dr. Matija Gams from the University of Ljubljana for the support and fruitful discussions during the execution of experimental campaign within "Development of an innovative approach for decoupling infills and non load-bearing masonry walls from the main structure" project. 


\section{REFERENCES}

[1] Liberatore, L., and Mollaioli, F. (2015). Influence of masonry infill modelling on the seismic response of reinforced concrete frames. Civil-Comp Proceedings, 108.

[2] Stavridis, A. (2009). Analytical and experimental study of seismic performance of reinforced concrete frames infilled with masonry walls. University of California, San Diego.

[3] L.D. Decanini, A. De Sortis, L. Liberatore, F. Mollaioli, "Estimation of near source ground motion and seismic behaviour of RC framed structures damaged by the 1999 Athens earthquake", Journal of Earthquake Engineering, 9(5), 609-635, 2005.

[4] Decanini, L. D., Liberatore, L., \& Mollaioli, F. (2012). Damage potential of the 2009 L'Aquila, Italy, earthquake. Journal of Earthquake and Tsunami, 6(03), 1250032.

[5] Tasligedik, A. S., \& Pampanin, S. (2017). Rocking cantilever clay brick infill wall panels: a novel low damage infill wall system. Journal of Earthquake Engineering, 21(7), 1023-1049.

[6] Butenweg, C., Marinković, M., \& Salatić, R. (2019). Experimental results of reinforced concrete frames with masonry infills under combined quasi-static in-plane and out-ofplane seismic loading. Bulletin of Earthquake Engineering, 17(6), 3397-3422.

[7] Fardis MN, Panagiotakos TB (1997) Seismic design and response of bare and masonryinfilled reinforced concrete buildings part II: infilled structures. J Earthq Eng $1(03): 475-503$

[8] Masi A (2003) Seismic vulnerability assessment of gravity load designed R/C frames. Bull Earthq Eng 1(3):371-395

[9] Verderame GM, De Luca F, Ricci P, Manfredi G (2011) Preliminary analysis of a softstorey mechanism after the 2009 L'Aquila earthquake. Earthq Eng Struct Dyn 40:925944

[10] Marinković, M., \& Butenweg, C. (2020). Out-of-plane behavior of decoupled masonry infills under seismic loading. In 17th World Conference on Earthquake Engineering.

[11] McDowell, E. L., McKee, K. E., and Sevin, E. (1956a). -Arching action theory of masonry walls.\|l J. Struct. Div., 82(ST2), 915/1-915/18.

[12] McDowell, E. L., McKee, K. E., and Sevin, E. (1956b). —Discussion of arching action theory of masonry walls.\| J. Struct. Div., 1067, 27-40.

[13] Dawe J. L. and Seah C. K. (1989b). Out-of-plane resistance of concrete masonry infilled panels. Journal of the Canadian Society of Civil Engineering, Vol. 16, pp. 854864.

[14] Angel R., Abrams D., Shapiro D., Uzarski J. and Webster M. (1994). Behavior of Reinforced Concrete Frames with Masonry Infills. Cicil Engrg. Studies, Structural Re-search Series No. 589, UILU-ENG-94-2005, Dept. of Civil Engineering, University of Illinois at Urbana Champaign.

[15] Flanagan, R. D., and Bennett, R. M. (1999b). Bidirectional behavior of structural clay tile infilled frames. Journal of structural engineering, 125(3), 236-244. 
[16] Di Domenico, M. (2018). Out-of-plane seismic response and modelling of unreinforced masonry infill walls (Doctoral dissertation, $\mathrm{PhD}$ Dissertation. University of Naples Federico II).

[17] Marinković M., Innovative system for seismic resistant masonry infills in reinforced concrete frame structures ( $\mathrm{PhD}$ Thesis), University of Belgrade - Faculty of Civil Engineering, 2018.

[18] Manfredi, V. and Masi, A. (2014). Combining in-plane and out-of-plane behaviour of masonry infills in the seismic analysis of RC buildings. Earthquakes and Struc-tures, 6(5), 515-537.

[19] Akhoundi, F., Vasconcelos, G., \& Lourenço, P. (2020). Experimental out-of-plane behavior of brick masonry infilled frames. International Journal of Architectural Heritage, 14(2), 221-237.

[20] Braga, F., Manfredi, V., Masi, A., Salvatori, A., \& Vona, M. (2011). Performance of non-structural elements in RC buildings during the L'Aquila, 2009 earthquake. Bulletin of Earthquake Engineering, 9(1), 307-324.

[21] Asteris, P. G., Cavaleri, L., Di Trapani, F., \& Tsaris, A. K. (2017). Numerical modelling of out-of-plane response of infilled frames: State of the art and future challenges for the equivalent strut macromodels. Engineering Structures, 132, 110-122.

[22] INSYSME (2016). Innovative systems for earthquake resistant masonry in reinforced concrete buildings, http://www.insysme.eu.

[23] Development of an innovative approach for decoupling masonry infills and non loadbearing masonry walls from the main structure, https://www.cwe.rwthaachen.de/earthquake-engineering-projects/development-of-an-innovative-approachfor-decoupling-infills-and-non-load-bearing-masonry-walls-from-the-main-structure/

[24] DIN EN 1992-1-1 (2011) Eurocode 2: Bemessung und Konstruktion von Stahlbetonund Spann-betontragwerken - Teil 1-1: Allgemeine Bemessungsregeln und Regeln für den Hochbau; Deutsche Fassung EN 1992-1-1:2004 + AC:2010

[25] DIN EN 1998-1 (2010) Eurocode 8: Auslegung von Bauwerken gegen Erdbeben - Teil 1: Grundlagen, Erdbebeneinwirkungen und Regeln für Hochbauten; Deutsche Fassung EN 1998-1:2004 + AC:2009

[26] Timoshenko, S. P., and Woinowsky-Krieger, S. (1959). Theory of plates and shells. McGraw-hill.

[27] Hendry AW. (1973). The lateral strength of unreinforced brickwork. Struct Eng;51(2):43-50.

[28] Hendry AW, Kheir AMA. (1976) The lateral strength of certain brickwork panels. In: Proceedings of the fourth international brick masonry conference, Brugge, Belgium.

[29] Haseltine, B.A. (1976) Design of laterally loaded wall panels. Proceedings of the British Ceramic Society, vol. 5(24). UK: Load Bearing Brickwork. Stoke-on-Trent; p. 115-26.

[30] Haseltine, B. A., West, H. W. H. and Tutt, J. N. (1977). Design of walls to resist lateral loads. Struct Eng;55(10):422-30. 
[31] Flanagan, R. D., and Bennett, R. M. (1999c). Arching of masonry infilled frames: Comparison of analytical methods. Practice Periodical on Structural Design and Construction, 4(3), 105-110.

[32] Thomas, F. G. (1953). The Strength of Brickwork. The Structural Engineer, Part 2, Vol. 36 , pp. 35-41.

[33] Anderson, C., and Bright, N. J. (1976). Behaviour of non-loadbearing block walls under wind loading. Concrete, 10(9), 27-30.

[34] Fricke, K. E., Jones, W. D., and Huff, T. E. (1992). In situ lateral load testing of an unre-inforced masonry hollow clay tile wall. Proc., 6th Can. Masonry Symp., University of Saskatchewan, Saskatoon, Saskatchewan, 519-530.

[35] Frederiksen, V. T. (1992, June). Membrane effect in laterally loaded masonry walls: a second order phenomenon. In Proceedings of the 6th Canadian Masonry Symposium, University of Saskatchewan, Saskatoon, Saskatchewan (pp. 537-547).

[36] EN 1998-1 (2004). Eurocode 8: Design of structures for earthquake resistance. Part 1: General rules, seismic actions and rules for buildings (EN 1998-1). CEN, Brussels, Belgium.

[37] EN 1996-1-1 (2005). Eurocode 6: Design of masonry structures. Part 1-1: General rules for reinforced and unreinforced masonry structures (EN 1996-1). CEN, Brussels, Belgium.

[38] Moghaddam, H., \& Goudarzi, N. (2010). Transverse resistance of masonry infills. $A C I$ Structural Journal, 107(4), 461-467.

[39] Morandi, P., Hak, S., \& Magenes, G. (2013). Simplified out-of-plane resistance verification for slender clay masonry infills in RC frames. Proceedings of the $X V$ ANIDIS, L'Ingegneria Sismica in Italia, Padua, Italy, 30.

[40] Ricci, P., Di Domenico, M., \& Verderame, G. M. (2018). Empirical-based out-of-plane URM infill wall model accounting for the interaction with in-plane demand. Earthquake Engineering \& Structural Dynamics, 47(3), 802-827. 